\title{
Curing of a Lysogenic Strain of Streptococcus cremoris and Characterization of the Temperate Bacteriophage
}

\author{
By D. GEORGHIOU, $\dagger$ S. H. PHUA AND E. TERZAGHI* \\ Department of Microbiology and Genetics, Massey University, Palmerston North, \\ New Zealand
}

(Received 2 January 1980; revised 12 August 1980)

\begin{abstract}
A derivative of Streptococcus cremoris MU0001 $\left(\mathrm{R}_{1}\right)$ has been isolated which has been cured of an inducible prophage. This isolate, its parent strain and a relysogenized derivative of the cured strain have been compared with respect to their ultraviolet inducibility, production of plaque-forming units, bacteriophage immunity and milk coagulation properties. The bacteriophage ( $\phi \mathrm{MU} 1)$ harboured by strain MU0001 as a prophage has been characterized by isopycnic density gradient centrifugation, electron microscopy and sodium dodecyl sulphate gel electrophoresis. Antiserum raised against this bacteriophage was used to demonstrate true lysogeny in both the original strain and the relysogenized strain.
\end{abstract}

\section{INTRODUCTION}

The streptococci are a diverse group of bacteria, many of which are pathogenic, for which reason they have been relatively well characterized (Deibel \& Seeley, 1974). Group N streptococci, commonly known as lactic streptococci, are chain-forming and non-pathogenic; they are used extensively in lactose fermentations, particularly in the production of a variety of cheeses. The literature regarding the dairy microbiology of these organisms is extensive, but little is known of their genetic systems (Lawrence et al., 1976). The origins of some of the bacteriophage which infect these organisms, resulting in fermentation failures, can probably be attributed to widespread lysogeny in the starter bacteria themselves (Terzaghi \& Sandine, 1981; Huggins \& Sandine, 1977; Reiter \& Kirikova, 1976; Lowrie, 1974), although other sorts of stable association of bacteria and bacteriophage have been suggested (Barksdale \& Arden, 1974). However, further careful and systematic studies of the putative lysogeny have been hindered by a general inability to find indicator strains for the bacteriophage found in induced lysates or to isolate strains cured of their putative prophage. Accordingly, a strict demonstration of lysogeny by the three generally accepted criteria [inducibility, immunity and resistance of the lysogenic state to antiserum raised against the lysogenic bacteriophage (Barksdale \& Arden, 1974)] has not previously been carried out. Furthermore, very little is known of the physiological effects accompanying the lysogenic state in lactic streptococci in terms of lysogenic conversion or immunity. Such information is vital both for understanding and controlling bacteriophage infections in dairy fermentations and for selection of improved strains.

To this end and in order to establish a firm base from which other lactic streptococcal strains and bacteriophages could be systematically studied, one presumptive lysogenic strain, MU0001 (Lowrie, 1974), was selected for curing and detailed characterization. By the above criteria we have confirmed true lysogeny in this system. In addition, the bacteriophage produced by strain MU0001, which may be propagated either lytically or lysogenically, has been characterized with respect to morphology, buoyant density and sodium dodecyl sulphate gel electrophoresis.

\footnotetext{
$\dagger$ Present address: Thalassaemia Centre, Nicosia General Hospital, Nicosia, Cyprus.
} 


\section{METHODS}

Bacteria and bacteriophage. Streptococcus cremoris strains MU0001 and MU0002 were obtained from the New Zealand Dairy Research Institute as strains $R_{1}$ and 368 , respectively. The latter was previously referred to as the indicator strain $\mathrm{AM}_{1}$ (Lowrie, 1974) but was, in fact, a slow milk-coagulating derivative of that strain and has therefore been given a new designation. Strain MU0003 is a cured derivative of MU0001 described below, and MU0004 is a relysogenized derivative of MU0003.

Bacteriophage $\phi \mathrm{MU1}$ was obtained by u.v. irradiation of strain MU0001, as described below. This bacteriophage was propagated lytically on either strain MU0002 or strain MU0003 and designated, respectively, $\phi \mathrm{MU} 1 / \mathrm{MU} 0002$ and $\phi \mathrm{MU} 1 / \mathrm{MU} 0003$. A spontaneous clear plaque derivative of $\phi \mathrm{MU} 1 / \mathrm{MU} 0003$ was isolated and is designated $\phi \mathrm{MU} 1$ (cl). This variant was used when higher titres of $\phi \mathrm{MU} 1$ grown lytically on MU0003 were required. The wild-type $\phi \mathrm{MU} 1$ generally yielded only very low titre stocks when grown lytically on MU0003.

The coliphage $\lambda$ and the $\lambda$ indicator Escherichia coli strain AB3013 were used in the density gradient analyses.

Media and diluent. M17 broth and agar media were used for growth as previously described (Terzaghi \& Sandine, 1975). Titrations of bacteria and bacteriophage were done in standard saline citrate which contained $8.8 \mathrm{~g} \mathrm{NaCl}$ and $4.4 \mathrm{~g} \mathrm{Na}_{3}$ citrate $2 \mathrm{H}_{2} \mathrm{O}$ in 11 water. Prior to use this diluent was supplemented with $1 \mathrm{~mm}-\mathrm{MgSO}_{4}$. Phosphate buffer ( $\mathrm{pH} \mathrm{7.2),} \mathrm{used} \mathrm{in} \mathrm{antiserum} \mathrm{reactions,} \mathrm{contained} 17.9 \mathrm{~g} \mathrm{Na} \mathrm{HPO}_{4} .12 \mathrm{H}_{2} \mathrm{O}(0.05 \mathrm{M}), 3.4 \mathrm{~g}$ $\mathrm{KH}_{2} \mathrm{PO}_{4}(0.025 \mathrm{M}), 4 \mathrm{~g} \mathrm{NaCl}$ and $1 \mathrm{~g}$ gelatin in 11 water.

For growth of strain $\mathrm{AB} 3013$ and titration of $\lambda, 2 \%(\mathrm{w} / \mathrm{v})$ Brain Heart Infusion (BHI) broth and BHI agar overlay plates were used.

Preparation of indicators. For titrating $\phi \mathrm{MU} 1$ on its homologous host (Terzaghi \& Terzaghi, 1978), a stationary culture grown in M17 broth was used. For titration on a heterologous host, the bacteria were grown to stationary phase in M17 plus $1 \%(\mathrm{w} / \mathrm{v})$ lactose and then allowed to age for $10 \mathrm{~d}$ at $4{ }^{\circ} \mathrm{C}$. The $\lambda$ indicator, strain $\mathrm{AB} 3013$, was prepared by growth of a culture in $2 \% \mathrm{BHI}$ broth to a titre of approximately $10^{9}$, sedimenting, resuspending in $1 \mathrm{~mm}-\mathrm{Mg}^{2+}$ and incubating with aeration at $37^{\circ} \mathrm{C}$ for $30 \mathrm{~min}$.

Ultraviolet induction. Cells were grown in M17 broth to an $A_{254}$ of 0.1 to 0.2 at $30^{\circ} \mathrm{C}$, chilled, centrifuged for $15 \mathrm{~min}$ at $6000 \mathrm{~g}$, and resuspended in $80 \%$ of the original volume of chilled $1 \mathrm{~mm}-\mathrm{MgSO}_{4}$. Resuspended cells $(3 \mathrm{ml})$ were irradiated for $15 \mathrm{~s}$ with a $15 \mathrm{~W}$ Philips TUV $\mathrm{P} / 40$ bactericidal lamp of wavelength $243.7 \mathrm{~nm}$ which delivered approximately 1 phage $\mathrm{T} 4$ hit per $3 \mathrm{~s}$. After irradiation, $6 \mathrm{ml} \mathrm{M} 17$ broth was added and incubation was continued at $30^{\circ} \mathrm{C}$ in the dark in order to minimize photoreactivation. To determine induction, the absorbance at $600 \mathrm{~nm}$ was read at intervals on a Bausch \& Lomb Spectronic 20 spectrophotometer.

Prophage curing. Cells were grown to approximately $2 \times 10^{8}$ chains $\mathrm{ml}^{-1}$ (as determined in a Petroff-Hauser counting chamber), washed twice in chilled $1 \%$ peptone, and treated for $2 \mathrm{~min}$ at high speed in an AtoMix blender. After centrifugation the cells were resuspended in phosphate buffer and irradiated to approximately $10^{-5}$ colony-forming units (c.f.u.) survival. The irradiated cells were then plated $(0.1 \mathrm{ml})$ on M17 plates without the usual $\mathrm{Ca}^{2+}$ supplementation and incubated overnight at $30^{\circ} \mathrm{C}$. Individual colonies were picked into $0.1 \mathrm{ml}$ broth in microtitre dishes (Linbro Multidish Dispo-trays) and grown for $3 \mathrm{~h}$ at $30^{\circ} \mathrm{C}$. They were then spotted $(0.05 \mathrm{ml})$ on to a master plate to test for viability and to provide an untreated sample of each isolate; the remaining $0.05 \mathrm{ml}$ aliquots were diluted with $0.2 \mathrm{ml}$ phosphate buffer and the whole tray was u.v.-irradiated for $15 \approx$. After $3 \mathrm{~h}$ incubation at $30^{\circ} \mathrm{C}$, each isolate was spotted on a lawn of sensitive MU0002 indicator bacteria (with $\mathrm{Ca}^{2+}$ supplementation) to test for the presence of induced bacteriophage by the criterion of production of a zone of lysis. Those irradiated isolates not producing zones of lysis after $16 \mathrm{~h}$ incubation were streaked from the master plate for single colonies, reisolated twice, and then tested for u.v. inducibility and the ability to support the growth of $\phi \mathrm{MU} 1$.

Isolation of relysogenized bacteria. Bacteria were picked from the centre of turbid plaques produced when the MU0001 induced lysate was plated on MU0003 bacteria; they were purified by two sequential single colony isolations.

Bacteriophage adsorption. Stationary phase cells were centrifuged and resuspended to the same cell density in fresh M17 broth. Equal volumes of bacteria and bacteriophage were mixed, incubated for $10 \mathrm{~min}$ at $30{ }^{\circ} \mathrm{C}$ and centrifuged for $15 \mathrm{~min}$ at $6000 \mathrm{~g}$. A portion of the supernatant was carefully removed and assayed for unadsorbed bacteriophage.

Isopycnic density gradient analysis. Bacteriophage preparations to be analysed in $\mathrm{CsCl}$ density gradients were first clarified by centrifuging for $10 \mathrm{~min}$ at $6000 \mathrm{~g}$ and then concentrated (along with portions of the coliphage $\lambda$ ) by sedimentation at $120000 \mathrm{~g}$ for $3 \mathrm{~h}$. The pellets were resuspended gently at $4{ }^{\circ} \mathrm{C}$ in $\mathrm{CsCl}$ (BDH, AnalaR) made up to a density of $1.48 \mathrm{~g} \mathrm{ml}^{-1}$ in $0.05 \mathrm{M}$-Tris $/ \mathrm{HCl}$ buffer $\mathrm{pH} 7 \cdot 2$. The samples were then centrifuged for 36 to $48 \mathrm{~h}$ at 30000 rev. min $^{-1}$ in the SW50. 1 rotor of a Beckman ultracentrifuge. The resulting gradients were displaced by pumping Fluorinert into the bottom of the tube, scanned and fractionated with an ISCO UA-5 monitor fitted with a type 6 optical unit and an ISCO 640 density gradient fractionator. The refractive index of each fraction was measured on an Atago Abbe refractometer, then an equal volume of M 17 broth was added and each fraction was assayed for bacteriophage titres ( $\phi \mathrm{MU} 1$ or $\lambda$ ) on the appropriate hosts.

For preparative purposes, preformed $\mathrm{CsCl}$ step gradients were constructed in Beckman SW41 tubes by adding 
successive $1 \mathrm{ml}$ portions of $\mathrm{CsCl}$ solutions (in $0.05 \mathrm{M}$-Tris $/ \mathrm{HCl} \mathrm{pH} \mathrm{7.2)} \mathrm{of} \mathrm{densities} 1.60,1.50,1.40$ and $1.30 \mathrm{~g} \mathrm{ml}^{-1}$. The sample containing the bacteriophage was layered on top to fill the tube and the gradient was centrifuged at $30000 \mathrm{rev} . \mathrm{min}^{-1}$ for $3 \mathrm{~h}$. The gradient was fractionated and the bacteriophage were recovered from the region corresponding to the top of the $1.50 \mathrm{~g} \mathrm{ml}^{-1}$ zone.

Electron microscopy. Samples $(5 \mathrm{ml}$ ) of bacteriophage preparations (either lytic stock or u.v.-induced lysates) from which bacterial debris had been removed by centrifuging at $6000 \mathrm{~g}$ for $10 \mathrm{~min}$ were sedimented at $105000 \mathrm{~g}$ for $2 \mathrm{~h}$. The pellet was allowed to resuspend slowly in $0.5 \mathrm{ml} 0.1 \mathrm{M}$-ammonium acetate. The Formvar/ carbon-coated copper grids were floated, carbon side down, on a drop made of equal parts of bacteriophage suspension and a $1: 1$ mixture of $2 \%(\mathrm{w} / \mathrm{v})$ potassium phosphotungstate $(\mathrm{pH} 4.0)$ and $2 \%(\mathrm{w} / \mathrm{v})$ ammonium molybdate. After 3 to $10 \mathrm{~min}$, the grids were rinsed with a drop of distilled water, drained, allowed to air dry and then examined in a Philips 200 electron microscope.

Sodium dodecyl sulphate $(S D S)$ polyacrylamide gel electrophoresis. Analyses were performed on slab gels $(120 \times 100 \times 1.5 \mathrm{~mm})$ using a discontinuous buffer and gel system. The lower gel and buffer were $10 \%(\mathrm{w} / \mathrm{v})$ acrylamide, $0.4 \%(\mathrm{w} / \mathrm{v})$ methylene bisacrylamide, $0.375 \mathrm{M}$-Tris $/ \mathrm{HCl} \mathrm{pH} 8.8$ and $0.1 \%(\mathrm{w} / \mathrm{v}) \mathrm{SDS}$. The upper gel and buffer were $4.5 \%$ acrylamide, $0.24 \%$ methylene bisacrylamide, $0.125 \mathrm{M}$-Tris $/ \mathrm{HCl} \mathrm{pH} 6.8$ and $0.1 \%$ SDS. Polymerization of both gels was catalysed by $0.025 \%(w / v)$ ammonium persulphate and $0.05 \%(w / v)$ $N, N, N^{\prime}, N^{\prime}$-tetramethylethylenediamine. The running buffer was $0.19 \mathrm{M}$-glycine, $0.025 \mathrm{M}$-Tris $/ \mathrm{HCl} \mathrm{pH} 8.3$ and $0.1 \%$ SDS. Gels were fixed and stained in $0.04 \%$ Coomassie Briliant Blue dissolved in $25 \%(\mathrm{v} / \mathrm{v})$ propan-2-ol and $10 \%(\mathrm{v} / \mathrm{v})$ glacial acetic acid. Destaining was done in $10 \%$ acetic acid. Molecular weight standards were provided by coliphage T4 purified on a CsCl step gradient (Vanderslice \& Yegian, 1974). Samples for electrophoresis were dialysed exhaustively against distilled water, disrupted by nine cycles of freezing and thawing followed by digestion with a few micrograms of DNAase and finally lyophilized. The samples were then dissolved in a portion (generally $50 \mu \mathrm{l}$ ) of sample buffer, which contained, per $100 \mathrm{ml}, 2.5 \mathrm{ml} \beta$-mercaptoethanol, $1.5 \mathrm{~g} \mathrm{SDS}$, $6.25 \mathrm{ml}$ upper Tris buffer, $8 \mathrm{ml}$ glycerol and $0.01 \mathrm{~g}$ bromophenol blue. Just prior to application, the samples were held at $100^{\circ} \mathrm{C}$ for 1 to $2 \mathrm{~min}$ to ensure complete dissociation of protein complexes.

Antiserum preparation and use. Approximately $10^{12}$ plaque-forming units (p.f.u.) of bacteriophage that had been purified on a sucrose gradient $[10$ to $30 \%(\mathrm{w} / \mathrm{v})$ sucrose in $0.05 \mathrm{M}$-Tris/ $\mathrm{HCl} \mathrm{pH} 7 \cdot 2$, centrifuged for $1 \mathrm{~h}$ $40 \mathrm{~min}$ at $25000 \mathrm{rev} . \mathrm{min}^{-1}$ in a Beckman SW27 rotor] were suspended in $0.6 \mathrm{ml} 0.05 \mathrm{M}-\mathrm{Tris} / \mathrm{HCl} \mathrm{pH} 7.2 \mathrm{plus}$ $0.6 \mathrm{ml}$ Freund's complete adjuvant and shaken to yield an emulsion. Then $0.5 \mathrm{ml}$ was injected intramuscularly into each hind leg of an immunologically fresh rabbit. The rabbits were reinoculated at 4 weeks, this time using incomplete adjuvant, and the serum was harvested $10 \mathrm{~d}$ afterwards. For determining the kinetics of bacteriophage inactivation $1.8 \mathrm{ml}$ antiserum at the appropriate concentrations in phosphate buffer was equilibrated at $20^{\circ} \mathrm{C}$ and then $0.2 \mathrm{ml}$ bacteriophage in phosphate buffer (approximately $10^{6}$ p.f.u. $\mathrm{ml}^{-1}$ ) was added. Samples were taken at appropriate times and titrated in the normal fashion.

\section{R.ESULTS AND DISCUSSION}

\section{Bacterial strains}

Streptococcus cremoris strain MU0001 was chosen for curing for three reasons. (1) Streptococcus cremoris strains are preferred to $S$. lactis strains for cheesemaking and strain MU0001 had been used as a cheese starter culture. (2) Strain MU0001 had previously been shown to be inducible by both mitomycin C and u.v. radiation (Lowrie, 1974). (3) An indicator sirain (MU0002) had been found for the bacteriophage in the induced lysate (Lowrie, 1974). As evidence of curing, we chose the criteria of a lack of lytic response to a known inducing agent (u.v.), failure to detect bacteriophage particles in an induced lysate either by plaque production on the known indicator or by electron microscopic examination, and the ability to serve as an indicator for phage $\phi \mathrm{MU} 1$.

Isolation of a prophage-cured bacterium. Using the method described, approximately $2 \%$ of the u.v. survivors appeared to be cured of their prophage by the criteria of failure to lyse or to produce p.f.u. when spotted on strain MU0002 following an inducing dose of u.v. and, perhaps most importantly, by acquisition of bacteriophage indicator capacity as shown by the formation of turbid plaques when plated with a diluted u.v.-induced lysate of strain MU0001. One of these cured isolates (MU0003) was further purified.

Relysogenization. As a confirmation of curing, we wished to relysogenize strain MU0003 with the bacteriophage induced from MU0001 and thereby reconstruct the MU0001 strain. From the turbid plaques a bacterium (designated MU0004) was isolated which showed lytic 


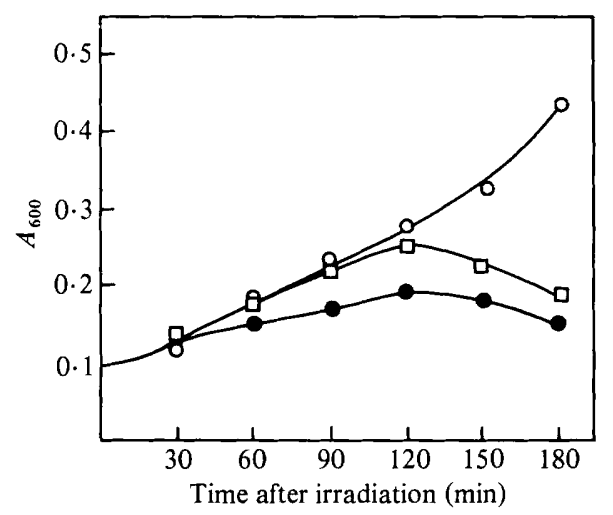

Fig. 1. Response of strains MU0001 (O), MU0003 (O) and MU0004 (口) to an inducing dose of u.v. radiation. Exponential phase cultures of these strains, which had been passaged through anti- $\phi \mathrm{MU} 1$ serum, were irradiated in chilled $1 \mathrm{mM}-\mathrm{MgSO}_{4}$, then allowed to grow in $\mathrm{M} 17$ broth at $30^{\circ} \mathrm{C}$. The absorbance was followed at $600 \mathrm{~nm}$; the results are shown with all absorbances at time 0 (the end of irradiation) normalized to $0 \cdot 1$.

sensitivity to u.v., produced p.f.u. on MU0002 and MU0003 following u.v. induction and no longer served as an indicator for $\phi \mathrm{MU} 1$.

Antiserum passage. To ensure that the bacterial strains which were to be examined with respect to their lysogenic property were free of externally carried bacteriophage, they were exhaustively treated with antiserum raised against purified $\phi M U 1$. Suspensions of strains MU0001 and MU0004, containing approximately $10^{4}$ and $5 \times 10^{2}$ p.f.u. $\mathrm{ml}^{-1}$, respectively, of spontaneously liberated bacteriophage, were prepared in M17 broth containing antiserum at a $k$ value of 20 (Adams, 1950), which had been shown to inactivate the homologous bacteriophage to fewer than $10^{-3}$ survivors. These mixtures were incubated for $1 \mathrm{~h}$ at $30^{\circ} \mathrm{C}$ and then streaked out for single colonies. The procedure was repeated and the final isolate was grown overnight in M17 broth in the presence of antiserum at a $k$ value of 20 . These overnight cultures were used in the following experiments to demonstrate the lysogenic state.

Ultraviolet induction. Antiserum-treated cultures of strains MU0001 and MU0004, as well as the cured strain MU0003, were u.v.-induced and their growth and lysis were followed spectrophotometrically (Fig. 1). The bacteriophage yields for both MU0001 and MU0004 following u.v. treatment were approximately $10^{10}$ p.f.u. $\mathrm{ml}^{-1}$ titrated on MU0003 per $0 \cdot 1 A_{600}$ unit measured at the time of irradiation. It is interesting to note that while the cured strain, MU0003, appears quite insensitive to a small dose of irradiation, both lysogenized strains are sensitive, with the original strain, MU0001, showing a distinctly greater sensitivity than the reconstructed lysogen MU0004. Although there is no further evidence which bears on this point, it is possible that the original strain was cured of more than just the prophage of $\phi \mathrm{MU} 1$ in the process of generating strain MU0003. The observed differences in u.v. response were reproducible and identical to those observed with cultures that had not been exposed to anti- $\phi$ MU1 serum. This experiment demonstrates that the lysogenic state, as measured by the lytic response to u.v. irradiation and the production of p.f.u. by both the original and the reconstructed strains, persists in spite of treatment with antiserum specific for the induced bacteriophage, and demonstrates that bacteriophage, or prophage, are carried internally.

Bacteriophage adsorption and immunity. When the u.v.-induced lysates generated in the experiments described above were plated on MU0001 and MU0004, no plaques appeared, indicating an efficiency of plating (e.o.p.) lower than $10^{-9}$ relative to the titre on the cured strain MU0003. To ascertain that the inability to form plaques in MU0001 and MU0004 was due to immunity rather than resistance, strains MU0001, MU0002, MU0003 and MU0004 were compared for their ability to adsorb $\phi \mathrm{MU} 1$. For this and most subsequent experiments, $\phi \mathrm{MU} 1$ was propagated on either MU0002 or MU0003 and designated, respectively, 
Table 1. Adsorption and efficiency of plating of $\phi M U 1$ on lysogenic, cured and original indicator strains of bacteria

Stationary phase cells were centrifuged and resuspended in an approximately equal volume of fresh M17 broth such that each preparation had a similar cell density, as measured spectrophotometrically. A known number of phage was added at a multiplicity of less than one and allowed to adsorb for $10 \mathrm{~min}$ at $30^{\circ} \mathrm{C}$. Remaining unadsorbed phage were measured by titrating the supernatant following centrifugation; the results are reported as percentage phage adsorbed ( $\%$ ads.). The efficiency of plating (e.o.p.) of a phage on its homologous host is defined as 1.0 .

\begin{tabular}{|c|c|c|c|c|c|c|c|c|}
\hline \multirow[b]{3}{*}{ Bacteriophage } & \multicolumn{8}{|c|}{ Bacterial host } \\
\hline & \multicolumn{2}{|c|}{ MU0001 } & \multicolumn{2}{|c|}{ MU0002 } & \multicolumn{2}{|c|}{ MU0003 } & \multicolumn{2}{|c|}{ MU0004 } \\
\hline & $\%$ ads. & e.o.p. & $\%$ ads. & e.o.p. & $\%$ ads. & e.o.p. & $\%$ ads. & e.o.p. \\
\hline$\phi \mathrm{MU} 1 / \mathrm{MU} 0002$ & 94 & $<10^{-9}$ & 94 & 1.0 & 73 & $\approx 10^{-5}$ & 90 & $<10^{-9}$ \\
\hline$\phi \mathrm{MU} 1 / \mathrm{MU} 0003$ & 88 & $<10^{-9}$ & 97 & $\approx 10^{-6}$ & 64 & $1 \cdot 0$ & 96 & $<10^{-9}$ \\
\hline
\end{tabular}

$\phi \mathrm{MU} 1 / \mathrm{MU} 0002$ and $\phi \mathrm{MU} 1 / \mathrm{MU} 0003$. As shown in Table 1, all four bacterial strains adsorbed both phage preparations in excess of $60 \%$; strains MU0001 and MU0004, in particular, adsorbed phage very well. Thus, the inability of the latter two strains to support the growth of $\phi \mathrm{MUl}$ must reside elsewhere and is considered to be a manifestation of lysogenic immunity.

Examination of the plating efficiency of $\phi \mathrm{MU} 1 / \mathrm{MU} 0002$ and $\phi \mathrm{MU} 1 / \mathrm{MU} 0003$ on their respective homologous and heterologous hosts (as well as the two lysogenized strains) gave the results shown in Table 1. As expected, neither lysogenized strain served as a host for these bacteriophage stocks, while the cured strain and original indicator did, but at dramatically different efficiencies, depending on the identity of the indicating host and the immediately preceding propagating host. When the indicating strain and immediately preceding propagating strain were the same (homologous host) there was a high e.o.p. (defined as 1.0); when the indicating strain and immediately preceding propagating strain were different (heterologous host) there was a very low e.o.p. Although the results are formally reminiscent of the classical Escherichia coli modification/restriction system, it was found (Terzaghi \& Terzaghi, 1978) that the degree of restriction manifested in the heterologous host varied over many orders of magnitude according to the physiological state of the host cells.

Physiological characterization. Strains MU0001 and MU0003 were compared for their acid production in milk, their speed of milk coagulation, their ability to utilize various sugars (lactose, glucose, galactose and sucrose) and their inability to deaminate arginine. In all of these respects, the two strains were identical, which suggests that lysogenization with $\phi \mathrm{MU} 1$ does not alter any of the gross physiological features of the bacteria that may be of commercial importance (Georghiou, 1976).

\section{Bacteriophage $\phi M U 1$}

To ascertain that the bacteriophage liberated by strains MU0001 and MU0004 by u.v. irradiation are not only identical with one another but are also the same as that propagated on strain MU0002 and MU0003, a detailed examination of the physical characteristics of this bacteriophage was undertaken.

Electron microscopy. Electron micrographs of the four bacteriophage preparations showed them to be morphologically identical, within the limits of resolution afforded by this technique (Fig. 2). The isometric head is approximately $50 \mathrm{~nm}$ in diameter and the striated tail with about 30 annuli is approximately $120 \mathrm{~nm}$ long. In some of these micrographs there is a hint of a collar structure at the junction of the head and tail, which is occasionally clear but often is not visible. As the apparent presence or absence of the collar is not convincingly correlated with the host used in the bacteriophage preparation we tentatively conclude that this 

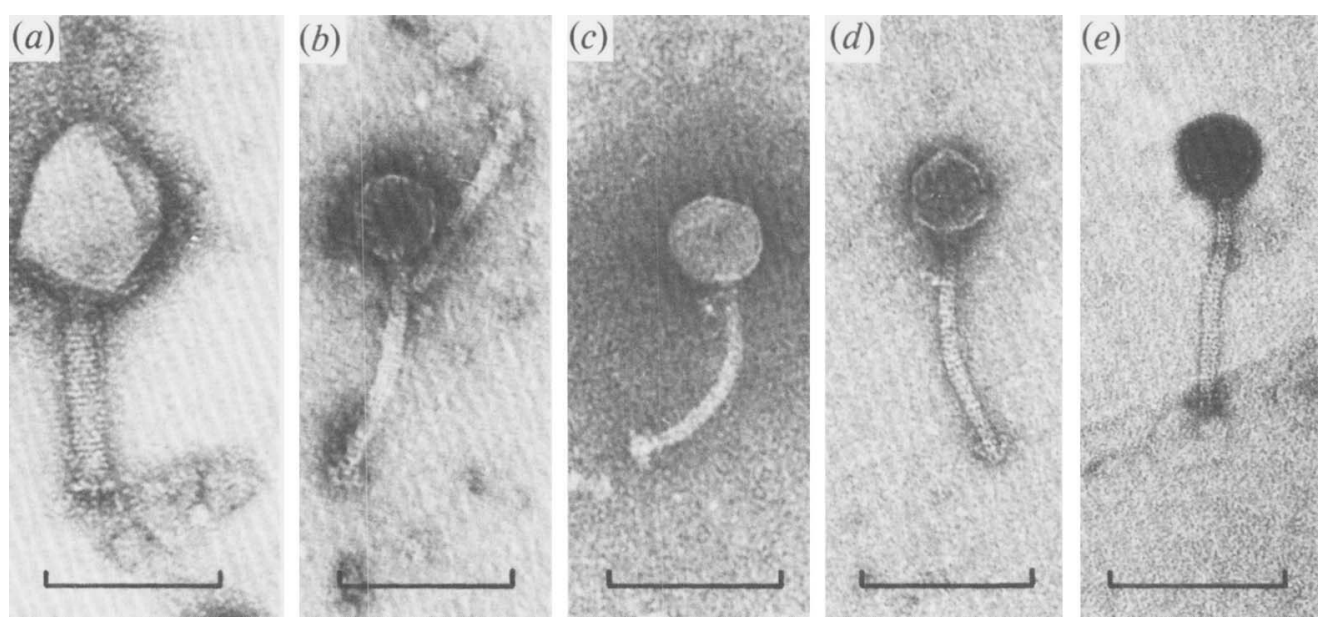

Fig. 2. Electron micrographs of bacteriophage $\phi \mathrm{MU} 1$ negatively stained with ammonium molybdate and potassium phosphotungstate. (a) Coliphage T4 used as an internal calibration standard; (b) $\phi \mathrm{MU} 1$ recovered directly from a u.v.-induced lysate of MU0001; (c) $\phi \mathrm{MU1}$ recovered directly from a u.v.-induced lysate of MU0004; (d) $\phi \mathrm{MU} 1 / \mathrm{MU} 0002 ;(e) \phi \mathrm{MU} 1 / \mathrm{MU} 0003$. Bar markers represent $100 \mathrm{~nm}$ as measured by the spacings of the annuli of the bacteriophage T4 tail, which agreed well with the known instrument magnification factor.

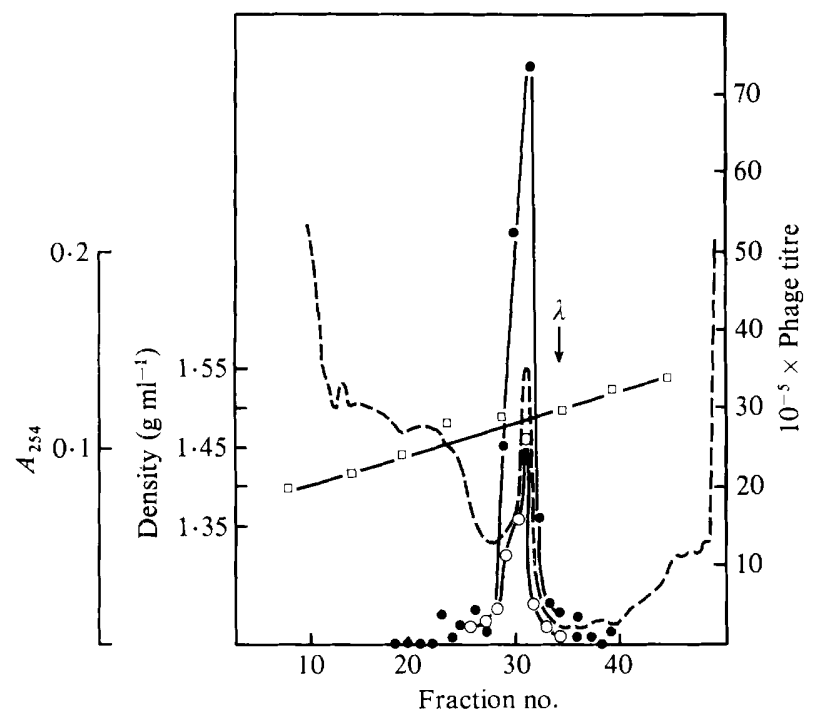

Fig. 3. $\mathrm{CsCl}$ density gradient analysis of a u.v.-induced lysate of strain MU0004. Bacteriophage that had been freed of bacterial debris by low-speed sedimentation were sedimented at high speed and then resuspended in $\mathrm{CsCl}$ solution at a density of $1.48 \mathrm{~g} \mathrm{ml}^{-1}$. This preparation was centrifuged at 30000 rev. min $^{-1}$ in the SW50.1 rotor of a Beckman ultracentrifuge for $36 \mathrm{~h}$. The gradient was displaced with Fluorinert through a u.v. monitor and $0.1 \mathrm{ml}$ fractions were collected. The gradient profile is shown in terms of $\phi \mathrm{MU} 1$ p.f.u. on MU0002 (O), $\phi \mathrm{MU} 1$ p.f.u. on MU0003 (O), the $A_{254}$ trace $(--)$ and the $\mathrm{CsCl}$ density $(\square)$ as measured by refractive index and normalized to a density of $1.500 \mathrm{~g} \mathrm{~m}^{-1}$ for $\lambda$.

bacteriophage does have a collar which is either difficult to visualize with the ammonium molybdate/potassium phosphotungstate negative stain employed in this study, or is fragile and often lost in the course of specimen preparation.

$\mathrm{CsCl}$ density gradient analysis. Preparations of u.v.-induced lysates of MU0001 and 


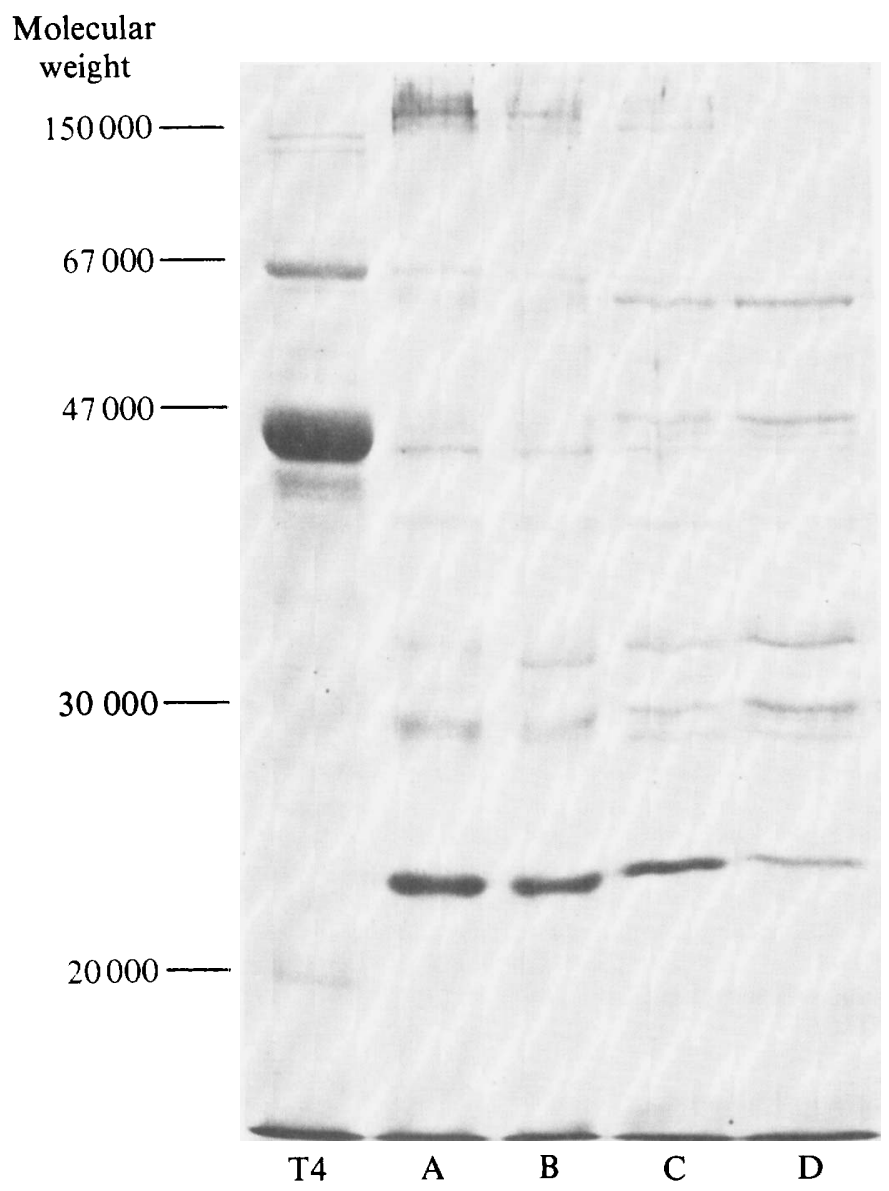

Fig. 4. SDS gel electrophoresis of $\phi \mathrm{MU1}$. Each preparation of $\phi \mathrm{MU} 1$ (50 ml, approximately $10^{9}$ p.f.u. $\mathrm{ml}^{-1}$ ) was partially purified on a $\mathrm{CsCl}$ step gradient, exhaustively dialysed against distilled water, disrupted by repeated cycles of freezing and thawing followed by DNAase digestion and lyophilized. The samples were resuspended in $50 \mu \mathrm{l}$ SDS sample buffer, heated to $100{ }^{\circ} \mathrm{C}$ for several minutes and $20 \mu \mathrm{l}$ portions were layered in the sample wells. Gels were run for $1 \mathrm{~h}$ at $12 \mathrm{~mA}$ and then for approximately $4 \mathrm{~h}$ at $20 \mathrm{~mA}$. Staining was done with Coomassie Brilliant Blue and destaining in $10 \%$ acetic acid. The T4 samples have been included to provide approximate molecular weight estimates (Vanderslice \& Yegian, 1974). A. $\phi \mathrm{MU} 1$ induced from MU0001; B, $\phi \mathrm{MU} 1$ induced from MU0004; C, $\phi \mathrm{MU} 1 / \mathrm{MU} 0003 ; \mathrm{D}, \phi \mathrm{MU} 1 / \mathrm{MU} 0002$.

MU0004 and lytic stocks of $\phi \mathrm{MU} 1 / \mathrm{MU} 0002$ and $\phi \mathrm{MU} 1 / \mathrm{MU} 0003$ were analysed by isopycnic density gradient centrifugation. The absorbance and p.f.u. profiles of one of these (MU0004 induced lysate) are shown in Fig. 3. Profiles of the other preparations were virtually identical in all respects. The main band of absorbance and p.f.u. in each case equilibrated at the same position in the gradient relative to $\lambda$ at a buoyant density of approximately $1.485 \mathrm{~g} \mathrm{ml}^{-1}$ (assigning a value of 1.500 to $\lambda$ ). While the profiles of the bacteriophage stocks and the u.v.-induced lysate of MU0004 show a single main peak of absorbance and p.f.u., the profile of the u.v.-induced lysate of MU0001 usually showed several additional small satellite peaks of p.f.u. Sampling of these satellite peaks and either re-running directly on a fresh gradient, or propagating these bacteriophage of apparently aberrant density, followed by a gradient analysis, invariably yielded single bacteriophage bands in the correct position relative to $\lambda$. We conclude that these satellite peaks are artefacts connected somehow with u.v. induction of MU0001, and have not pursued the matter. It thus 


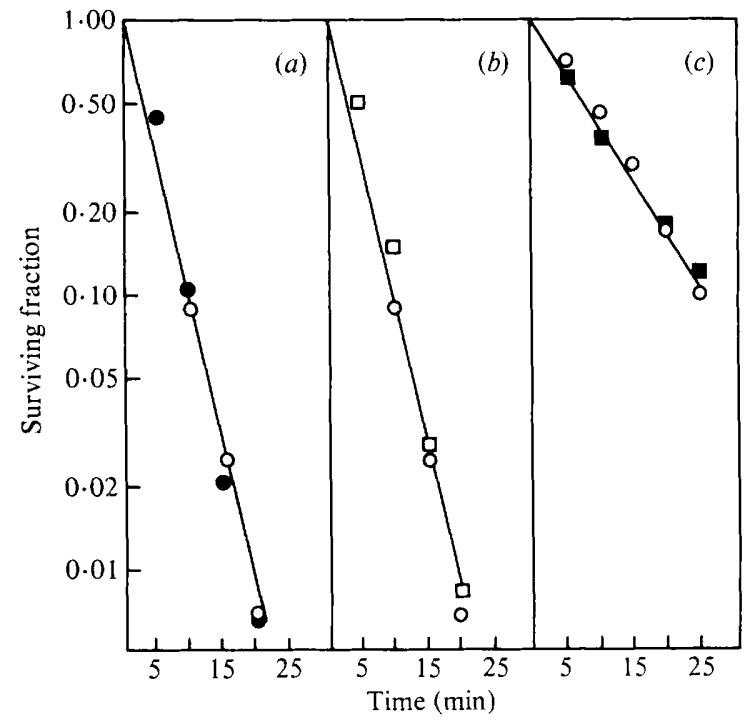

Fig. 5. Antiserum inactivation of $\phi \mathrm{MU} 1$. Antiserum was raised against $\phi \mathrm{MU} 1 / \mathrm{MU} 0002$ and the kinetics of inactivation by this antiserum of various preparations of $\phi \mathrm{MU} 1$ were examined by mixing diluted antiserum and bacteriophage at approximately $10^{6}$ p.f.u. $\mathrm{ml}^{-1}$. The mixtures were incubated at $20^{\circ} \mathrm{C}$ and samples were removed at the indicated times for titration. The surviving fraction is plotted (on a logarithmic scale) against time of incubation. In each case the inactivation of the homologous bacteriophage, $\phi \mathrm{MU} 1 / \mathrm{MU} 0002$, is shown (O). (a) Antiserum at a dilution of $10^{-4}$ incubated with $\phi \mathrm{MU} 1 / \mathrm{MU} 0003$ (O). (b) Antiserum at a dilution of $10^{-4}$ incubated with the bacteriophage induced from MU0004 ( $\square$ ). (c) Antiserum at a dilution of $5 \times 10^{-5}$ incubated with the bacteriophage induced from MU000I ( $\mathbf{\square})$.

appears that the four different preparations of the bacteriophage yield particles of identical buoyant density.

SDS gel electrophoresis. The gel patterns of $\phi \mathrm{MU} 1$ harvested from u.v.-induced lysates of MU0001 and MU0004, as well as from stocks grown on MU0002 and MU0003, are shown in Fig. 4. The patterns are substantially identical, differing primarily in the relative intensities of a few of the bands, which further supports the identity or near identity of the four preparations of $\phi \mathrm{MU} 1$. A detailed comparison of the patterns, however, raises some puzzling points. In tracks A and B are shown the patterns of the bacteriophage purified from induced lysates of, respectively, MU0001 and MU0004. While the two patterns appear identical with respect to band positions, in the region of molecular weight 32000 there is a reproducible reversal of band intensity. In tracks $C$ and $D$ are shown the patterns for the two lytically grown bacteriophage preparations (grown on, respectively, MU0003 and MU0002). Again, the patterns are grossly similar to each other and to the patterns produced by the phage purified from induced lysates. However, there are variations in band intensities in the regions of molecular weight 23000 and 30000 , and the cluster of three bands at about 47000 shows a slightly different spacing and relative intensity in the two types of bacteriophage preparations.

Recent work in our laboratory (unpublished) indicates that many of the strains of bacteria are lysogenic, or defectively lysogenic, for a number of very closely related phage, and that some phage stocks, hitherto regarded as homogeneous by the criteria used in this paper, are in fact subtly heterogeneous. Accordingly, we suspect that at least some of the variability in band density and position is due either to admixture of very closely related phage or to the acquisition by phage, perhaps by a process akin to 'marker rescue', of new structural genes from the host. 
Antigenic properties. Antiserum was prepared against $\phi \mathrm{MU} 1 / \mathrm{MU} 0002$ and used to determine the kinetics of inactivation of the p.f.u. in lytic preparations of $\phi \mathrm{MU} 1 / \mathrm{MU} 0002$ and of $\phi \mathrm{MU} 1 / \mathrm{MU} 0003$ as well as in u.v.-induced lysates of MU0004 and MU0001 (Fig. 5). The two stocks $\phi \mathrm{MU} 1 / \mathrm{MU} 0002$ and $\phi \mathrm{MU} 1 / \mathrm{MU} 0003$ and the induced lysates were inactivated with very similar kinetics. A parallel series of experiments with antiserum raised against $\phi \mathrm{MU} 1 / \mathrm{MU} 0003$ (cl) yielded identical results. Thus, it appears that, at least in respect to those antigenic sites which are related to the infection process, the four different preparations of $\phi \mathrm{MU} 1$ are identical.

\section{Conclusion}

The true lysogenic condition of $S$. cremoris strain MU0001 has been demonstrated (i) by virtue of the observation that lysogeny persists in the presence of antiserum specific for the bacteriophage concerned, and (ii) by the isolation of a strain that is cured of the lysogenic bacteriophage. As predicted on the basis of observations on other lysogenic systems, the original lysogen appears to be immune to the bacteriophage, while the cured strain serves as a host, forming turbid plaques when a bacterial lawn is seeded with the bacteriophage. A relysogenized strain was easily isolated from a turbid plaque and shown to have lysogenic and immunity properties substantially the same as those of the original lysogenic strain.

Bacteriophages liberated by u.v. induction of both the original lysogen MU0001 and the relysogenized derivative strain MU0004 were shown to be identical by the criteria of gross morphology, buoyant density, SDS gel electrophoresis pattern and antigenic specificity. By the same criteria, bacteriophages resulting from propagation of $\phi \mathrm{MU} 1$ on MU0002 or MU0003 are identical. Arising out of these studies, however, there is the problem of the nature of the physiologically labile e.o.p. depression of $\phi \mathrm{MU} 1$ when plated on its heterologous host which demands clarification.

The authors wish to thank Robert Cleaver for his expert technical assistance, the Electron Microscope Unit of the D.S.I.R. (Palmerston North) for help with the electron microscopy, Dr B. E. Terzaghi for much valuable discussion and advice and, finally, the New Zealand Dairy Research Institute and the Scientific Research Distribution Committee (N.Z.) for financial assistance. Portions of this work have been presented by D.G. and S.H.P. in partial fulfilment of the M.Sc. degree at Massey University.

\section{REFERENCES}

AdAms, M. H. (1950). Bacteriophages. New York: Interscience.

Barksdale, L. \& Arden, S. B. (1974). Persisting bacteriophage infections, lysogeny and phage conversions. Annual Review of Microbiology 28. 265299.

Deibel, R. H. \& Seeley, JR, H. W. (1974). In Bergey's Manual of Determinative Bacteriology, 8th edn, pp. 490-510. Edited by R. E. Buchanan \& N. E. Gibbons. Baltimore: Williams \& Wilkins.

Georghiou, D. G. (1976). Studies in lysogeny elimination of prophages from lysogenic strains of Streptococcus cremoris: 'curing' and lysogenic conversion. Thesis, Massey University, New Zealand.

Huggins, A. R. \& Sandine, W. E. (1977). Incidence and properties of temperate bacteriophages induced from lactic streptococci. Applied and Environmental Microbiology 33, 184-191.

Lawrence, R. C., Thomas, T. D. \& Terzaghi, B. E. (1976). Reviews of the progress of dairy science: cheese starters. Journal of Dairy Science 43 . 141-163.
LowRIE, R. J. (1974). Lysogenic strains of group N lactic streptococci. Applied Microbiology 27, 210217.

REITER, B. \& KiRIKova, M. (1976). The isolation of a lysogenic strain from a multiple strain starter culture. Journal of the Society of Dairy Technology 29, 221-225.

Terzaghi, B. E. \& Sandine, W. E. (1975). Improved medium for lactic streptococci and their bacteriophages. Applied Microbiology 29, 807-813.

Terzaghi, B. E. \& Sandine, W. E. (1981). Bacteriophage production following exposure of lactic streptococci to ultraviolet radiation. Journal of General Microbiology 122, 305-311.

Terzaghi, E. \& Terzaghi, B. E. (1978). Effect of lactose concentration on the efficiency of plating of bacteriophages on Streptococcus cremoris. Applied and Environmental Microbiology 35, 471-478.

VAnderslice, R. W. \& Yegian, C. D. (1974). The identification of late bacteriophage $\mathrm{T} 4$ proteins on sodium dodecyl sulfate polyacrylamide gels. Virology 60, 265-275. 